\title{
Continuation of dual anti-platelet therapy after drug-eluting \\ stents in primary angioplasty beyond 12 months [version 1;
}

\section{peer review: 2 approved]}

\section{Iman Mohasseb1, Christian A Gericke 2,3}

${ }^{1}$ Department of Cardiology, Plymouth Hospitals NHS Trust, Plymouth, PL6 8DH, UK

2PenCLAHRC, National Institute for Health Research, Peninsula Medical School, Plymouth, PL4 8AA, UK

${ }^{3}$ The Wesley Research Institute, Brisbane, QLD 4066, Australia

V1 First published: 21 Nov 2012, 1:53

https://doi.org/10.12688/f1000research.1-53.v1

Latest published: 21 Nov 2012, 1:53

https://doi.org/10.12688/f1000research.1-53.v1

\section{Abstract}

In this correspondence we discuss the results of the meta-analysis by De Luca et al. (2012) in the Archives of Internal Medicine which found that late myocardial reinfarction and stent thrombosis is more common in drug-eluting stents than in bare-metal stents. We discuss the clinical implications of this paper for dual anti-platelet therapy which did not receive sufficient attention in the original publication and the accompanying editorial.

\section{Open Peer Review \\ Approval Status \\ 1 \\ 2 \\ version 1 \\ 21 Nov 2012 \\ 1. Sripal Bangalore, New York University \\ School of Medicine, New York, NY, USA \\ 2. Bruce Biccard, Nelson R Mandela School of \\ Medicine University of Kwazulu-Natal, \\ Durban, South Africa \\ Any reports and responses or comments on the article can be found at the end of the article.}

Corresponding author: Christian A Gericke (christian.gericke@pcmd.ac.uk)

Competing interests: CAG is a member of the Asia-Pacific Advisory Board for Bayer Pharmaceuticals.

Grant information: We acknowledge funding from the National Institute for Health Research (NIHR) for CAG's contribution to this article. The views and opinions expressed in this paper are those of the authors and not necessarily those of the NHS, the NIHR or the Department of Health in England.

The funders had no role in study design, data collection and analysis, decision to publish, or preparation of the manuscript.

Copyright: $\odot 2012$ Mohasseb I and Gericke CA. This is an open access article distributed under the terms of the Creative Commons Attribution License, which permits unrestricted use, distribution, and reproduction in any medium, provided the original work is properly cited. Data associated with the article are available under the terms of the Creative Commons Zero "No rights reserved" data waiver (CC0 1.0 Public domain dedication).

How to cite this article: Mohasseb I and Gericke CA. Continuation of dual anti-platelet therapy after drug-eluting stents in primary angioplasty beyond 12 months [version 1; peer review: 2 approved] F1000Research 2012, 1:53

https://doi.org/10.12688/f1000research.1-53.v1

First published: 21 Nov 2012, 1:53 https://doi.org/10.12688/f1000research.1-53.v1 


\section{Correspondence}

The meta-analysis by De Luca et al. ${ }^{1}$ showed that the incidence of late (> 2 years) myocardial reinfarction and stent thrombosis is significantly higher in drug-eluting stents (DES) compared to bare-metal stents (BMS) in primary angioplasty despite the significant reduction in long-term target vessel revascularizationassociated with DES.

While the Comment section of the paper briefly mentions the role of more potent and prolonged dual anti-platelet therapy in countering these worrisome findings, the related Commentary ${ }^{2}$ does not. However, in our view the current practice of discontinuing dual anti-platelet therapy after 12 months in DES in most patients is the most likely explanation for the observed increase in late stent thrombosis and reinfarction incidence, in concordance with pathological evidence that even beyond 40 months, DES do not fully epithelialize ${ }^{3}$. In the De Luca et al. ${ }^{1}$ meta-analysis, the DES survival curves for both reinfarction and stent thrombosis start diverging from the BMS curves one year after stent implantation until year 6.

This also raises the most relevant question for practitioners: should we prolong dual anti-platelet therapy beyond 12 months after DES implantation? The Dual Antiplatelet Therapy Study (DAPT) is expected to give us a definitive answer to this question in $2014^{4}$.
For the time being, it seems that the argument to continue dual anti-platelet therapy beyond 12 months, which is fully in line with the current ACCF/AHA/SCAI recommendation ${ }^{5}$ to continue dual anti-platelet therapy for at least 12 months after DES implantation, has gained in strength.

\section{Author contributions}

IM drafted the first version of this correspondence article and IM and CAG have substantially revised it after discussion.

\section{Competing interests}

CAG is a member of the Asia-Pacific Advisory Board for Bayer Pharmaceuticals.

\section{Grant information}

We acknowledge funding from the National Institute for Health Research (NIHR) for CAG's contribution to this article. The views and opinions expressed in this paper are those of the authors and not necessarily those of the NHS, the NIHR or the Department of Health in England.

The funders had no role in study design, data collection and analysis, decision to publish, or preparation of the manuscript.
1. De Luca G, Dirksen MT, Spaulding C, et al.: Drug-Eluting vs Bare-Metal Stents in Primary Angioplasty: A Pooled Patient-Level Meta-analysis of Randomized Trials. Arch Intern Med. 2012; 172(8): 611-21. PubMed Abstract | Publisher Full Text

2. Brophy JM: Drug-Eluting Stents in ST-Segment Elevation Myocardial Infarction: Comment on "Drug-Eluting vs Bare-Metal Stents in Primary Angioplasty". Arch Intern Med. 2012; 172(8): 621-2. Publisher Full Text

3. Joner M, Finn AV, Farb A, et al.: Pathology of drug-eluting stents in humans: delayed healing and late thrombotic risk. J Am Coll Cardiol. 2006;
48(1): 193-202.

PubMed Abstract | Publisher Full Text

4. U.S. National Institutes of Health [cited 8 May 2012].

Reference Source

5. Levine GN, Bates ER, Blankenship JC, et al:: 2011 ACCF/AHA/SCAI Guideline for Percutaneous Coronary Intervention. A report of the American College of Cardiology Foundation/American Heart Association Task Force on Practice Guidelines and the Society for Cardiovascular Angiography and Interventions. J Am Coll Cardiol. 2011; 58(24): e44-122.

Publisher Full Text 


\section{Open Peer Review}

\section{Current Peer Review Status:}

\section{Version 1}

Reviewer Report 05 December 2012

https://doi.org/10.5256/f1000research.229.r376

(C) 2012 Biccard B. This is an open access peer review report distributed under the terms of the Creative Commons Attribution License, which permits unrestricted use, distribution, and reproduction in any medium, provided the original work is properly cited.

\section{Bruce Biccard}

Department of Anaesthetics, Nelson R Mandela School of Medicine University of Kwazulu-Natal, Durban, South Africa

Competing Interests: No competing interests were disclosed.

I confirm that I have read this submission and believe that I have an appropriate level of expertise to confirm that it is of an acceptable scientific standard.

Reviewer Report 29 November 2012

https://doi.org/10.5256/f1000research.229.r372

(C) 2012 Bangalore S. This is an open access peer review report distributed under the terms of the Creative Commons Attribution License, which permits unrestricted use, distribution, and reproduction in any medium, provided the original work is properly cited.

\section{Sripal Bangalore}

Department of Medicine, Cardiology Division, New York University School of Medicine, New York, NY, USA

Competing Interests: No competing interests were disclosed.

I confirm that I have read this submission and believe that I have an appropriate level of expertise to confirm that it is of an acceptable scientific standard. 
The benefits of publishing with F1000Research:

- Your article is published within days, with no editorial bias

- You can publish traditional articles, null/negative results, case reports, data notes and more

- The peer review process is transparent and collaborative

- Your article is indexed in PubMed after passing peer review

- Dedicated customer support at every stage

For pre-submission enquiries, contact research@f1000.com 